\title{
E-LOGOS
}

\section{Radek Adamec: EKONOMICKÁ VĚDA A HOSPODÁŘSKÁ POLITIKA}

"Praxe hospodářské politiky sice úzce navazuje na vývoj ekonomické teorie, ta však tvoři jen část inspirativních zdrojů hospodářské praxe." str. 6

Milan Žák: kap. 1.3. v Žák, M. a Němcová, I.: Učebnice hospodářské politiky I.,

Tato práce se pokouší vysvětlit a obhájit tvrzení opačné: "Vývoj ekonomické teorie úzce navazuje na praxi hospodářské politiky, protože ta tvoří hlavní část jeho inspirativních zdrojů." a v závěru také to, že způsob, jakým hospodářská politika navazuje na ekonomickou teorii jako na inspirační zdroj, znamená, že jednotlivé ekonomické teorie jsou pro účely hospodářské politiky užívány převážně selektivně jako nástroje pro interpretaci problémů, jež hospodářská politika řeší. Zároveň by mělo vyplynout, že ideologický (ideový či paradigmatický) náboj ekonomických teorií či škol, který vstupuje do tvorby a hodnocení hospodářskopolitických doporučení, není v ekonomii odstranitelný prostředky vědeckého př́istupu.

\section{Legalita a legitimita vědecké teorie}

Kdy je teorie rozeznáním "nové" obecné funkce systému "ideologickými" brýlemi obecnější (třeba jen intuitivní) meta-teorie jako podle návodu na identifikaci konkrétních závislostí a kdy je teorie zobecněním funkce systému kauzálně odvozeným z již dříve známých konkrétních závislostí? Takto položeno, není žádná teorie ani jedním ani druhým, ale vždy výsledkem rekurzivního opakování obou postupů. Smysluplnost, komunikovatelnost a použitelnost podstatné vědecké teorie krystalizuje vždy mezi nimi. /Na jedné straně je každé pozorování i samo vnímání vždy prosáknuto teorií. viz. Poper 1972 (1963). A na druhé straně každá ne holistická teorie je s pomocí abstrakce budována tzv. kompozitivní metodou. viz. Hayek 1979 a Adamec 1996./

Každý z obou postupů má však svá logická omezení. Kde je teorie více zobecněním empirické zkušenosti, vzniká otázka, nejde-li takové zobecňování nad rámec schopností jednotlivce vnímat tuto obecnost a tak zakoušet zkušenost. Tento převážně induktivní postup nezaručuje objektivitu. /K problému indukce viz. např. Popper 1972/ A na druhou stranu, kde je teorie více abstraktní, "ideologickou" hypotézou, vzniká otázka, jaký stupeň zkušenostní nebo výlučně empirické ověřitelnosti takové obecné hypotézy považovat za dostatečně príijatelný na to, aby byla vưbec připuštěna jako vědecká. /K problému pozorovacích tvrzení jako absolutní empirické 
báze viz. např. Popper v Logic of Scientific Discovery, 6. vyd., Londýn, Hutchinson, 1972 (1952), str. 111./ I přes tato omezení je však "teorie zobecněním" již dostatečně legitimní a tak vědecky legální díky empirické zkušenosti, která je vždy předem daná /viz.

pozitivistické metodologické školy ve filozofii vědy/, zatímco "ideologická teorie" je pouze legitimizována potenciálem (empirické) ověřitelnosti, tzn. dokazatelnosti nebo potvrditelnosti v duchu logického pozitivismu, či testovatelnosti (potenciálem vyvratitelnosti) v duchu popperiánské metodologie vědy, který závisí na prediktivním potenciálu jejích aplikací.

Domnívám se, že zatímco přírodní vědy klasicky řešily problém první, jenž se projevuje například $v$ tom, že pro uznání nebo jen zveřejnění teorie je dưležitá možnost pozorování a zásadního experimentu, společenské vědy se v téže době potýkaly $s$ problémem druhým, jež se naopak projevuje tak, že nezávisle na své popisné přesnosti (např. na nereálnosti předpokladů či nevyčíslitelnosti kategorií) je hodnocena explanační, resp. prediktivní schopnost teorie.

Ač je aplikace spočenskovědní teorie fakticky často experimentem s nepředvídatelnými vedlejšími důsledky a experiment v přírodních vědách často aplikací teorie s jasným záměrem, $z$ definice pojmů aplikace a experiment jsou teorie prírodních věd posuzovány experimentem, který je ve vědě legalizuje, a teorie věd společenských jsou posuzovány podle aplikace, která je svou užitnou hodnotou pro vědu pouze legitimuje. /Odtud možná Friedmanovo kontroverzní doporučení hodnotit pravdivost ekonomických teorií pouze podle úspěšnosti předpovědí. viz. Friedman, 1953./ V abstraktních vědách jako matematika či logika se jedná o uzavřený systém, uvnitř něhož se dokazuje konzistence teorie a jejích závěrů na základě axiomů, které jsou všechny její součástí.

Z historického hlediska by tak bylo možné označit prírodní vědy za vědeckou školu empirickou, či raději školou empirické legality, a sociální vědy za vědeckou školu ideologickou (ideovou), či školou aplikační legitimity. Současně je však třeba zdůraznit, že extenzivní rozvoj vědy v posledních sto letech naznačenou odlišnost mezi prírodními a společenskými vědami víceméně smazal, resp. nikdy ani nedošlo k jejímu obnažení, nebot' společenské vědy se srovnávaly s metodou přírodních věd jako se svým vzorem po celé období než se jako vědy vůbec emancipovaly /viz. např. Hayek, 1979/ a k seriózní reflexi své vlastní metody pokročily až dlouho po té. To už však rozeznání a pojmenování této dichotomie bránily jak divergence metod i předmětů zkoumání a prolínání odlišných metodologií, tak i redukce vědeckých standardů při existenci heterogenních metod na víceméně formální kritéria. Tradiční legalita vědecké teorie byla postupně shledána nepodstatnou /Viz. post-pozitivistická reakce ve vývoji filozofie vědy, jejíž hlavním protagonistou byl Karl Popper. viz. Adamec 1998/ a to mnohde i v přírodních vědách, jež byly vždy její klasickou doménou.

\section{Ekonomická proroctví}


Karl Popper $(1972,1979)$ proti argumentu pro rozlišování přírodních a společenských věd, že vědec je součástí zkoumaného, namítal, že obě postupují metodou pokusu a omylu, neboli podle jeho, tzv. hypoteticko-deduktivní metodologie. Milton Friedman (1953) odmítal kritiku ekonomických teorií založenou na hodnocení reálnosti jejich předpokladů, tedy vedenou z pozic školy empirické legality, a zdůrazňoval jako jediné podstatné kritérium hodnocení ekonomických teorií úspěch jejich předpovědí, neboli z pozice školy aplikační legitimity obhajoval jejich užitnou hodnotu.

V ekonomii však vědecky užitnou hodnotu předpovědí neproblematizuje ani tak to, že měření ovlivňuje měřené (tzv. Heisenbergův princip neurčitosti), ani to, že vědec je součástí zkoumaného, ale hlavně to, že předpovědi jsou dnes součástí předpovídaného, neboli obecně, že ekonomická věda je skrze své aplikace (a mezi nimi v první řadě skrz hospodářskou politiku) součástí svého předmětu zkoumání. /Zpětná vazba mezi teorií a objektem teorie jako odlišnost od přírodních věd viz. Morgenstern, Oskar. "Descriptive, Predictive and Normative Theory." Kyklos 225, no.4, 1972, str. 7067./ Např. předpovědi budoucího vývoje ekonomiky často spekulují na svůj vlastní vliv na tento vývoj a na druhou stranu je taková spekulace předem očekávána, což do značné míry její účinnost neutralizuje.

Vezmeme-li tento ekonomům a politikům dobře známý fakt do důsledků, můžeme sestrojit obecný model, ve kterém všeobecné uznání jistého objevu v ekonomické teorii a jeho adoptování do chování ekonomických subjektů /viz. Morgensternova teorie sebechránících proroctví (viz. Wirtschaftsprognose, eine Untersuchung ihrer Voraussetzungen und Möglichkeiten, Vídeň, Julius Springer Verlag, 1928) se postupně vyvinula v teorii "absorbce teorie" členy ekonomiky (1972 viz. výše)./ změní fungování reálné ekonomiky a to i natolik, že ekonomický systém přestane nadále daný, objevený jev vykazovat.

Např. rozšiření nové verze počítačového programu pro spekulace na fluktuaci kurzů akcií způsobí nejen jeho neúčinnost, ale i riziko ztrát, adoptování Keynesovy teorie zaměstnanosti do hospodářské politiky vyvolalo do té doby neznámý jev pádivé inflace, při kterém se ukázal postulát o zaměnitelnosti inflace za nezaměstnanost jako ne univerzálně platný a ne dlouhodobě užitečný co by koncept pro hospodářskou politiku. Podobný model nemožnosti sebeohrožující (non-self-defeating) předpovědi v určitých tržních hrách, kdy znalost teorie racionálního chování ze strany hráčủ ničí její prediktivní platnost, popsali Oscar Morgenstern a Gerhard Schwödiauer /"Competition and Collusion in Bilateral Markets" Zeitschrift für Nationalökonomie 36, 1976, str. 228./

Z metodologického hlediska je důležitějším poznatkem než zdánlivý paradox předešlého tvrzení to, že vedle jiných sociálních procesů může i ekonomická teorie sama sebe zásobovat (s jistým nezbytným zpožděním) novými reálnými jevy čekajícími na vysvětlení a že je $v$ přirozenosti ekonomické teorie i určitá sublimace užitné hodnoty jejích předpovědí v tento potenciál svého rozšíření a/nebo případného vystřídání jinou v té době méně frekventovanou teorií. 


\section{Ekonomie $\mathbf{v}$ čase}

Spíše než, že "ekonomie je v čase" /viz. Hicks, Sir John: "Is Economics a Science?", v Barazini and Scazzieri (vyd.): Foundations of Economics, Oxford, Basil Blackwell, 1986, str.91-101, str. 100: "Pokud je teorie dobrá, je dobrá ted' a byla by dobrá před tisíci lety, byla-li bývala k dispozici, ale aspekty ekonomického života, které potřebujeme vybrat, abychom vytvořily užitečné teorie mohou být rozdílné v rozdílných dobách (viz. Hicks 1976, 1983). Ekonomie je v čase, a proto v dějinách, způsobem, jímž věda není." pozn. Hicks 1976, 1983 znamená odkaz na: " 'Revolutions' in Economics" v Latsis, Spiro J. (vyd.) Method and Apprisal in Economics, Cambridge, Cambridge University Press, 1976, str. 207-18 a přetištěno v Classics and Moderns, díl 3. jeho Collected Essays on Economic Theory, Oxford, Basil Blackwell, 1983, str. 3-16./, bychom mohli ř́kat, že "ekonomie je v mezidobí". Aplikovaná ekonomická teorie totiž prochází jakýmsi "životním cyklem" od získávání popularity a uznání ve vědě $\mathrm{k}$ praktickému užívání, po té přes úspěch a nezamýšlené důsledky v praxi k vlastní problematizaci. Ne nepodobně ekonomickým cyklům trhu, politickým cyklům zastupitelské demokracie nebo životním cyklům výrobků se i životní cyklus ekonomické teorie stř́dá ve velkých i malých vinách nepravidelně, ale o to přesvědčivěji. /Není bez zajímavosti, jak analogicky jsou v těchto cyklech popisovány jak vývoj hospodářskopolitických koncepcí, tak vývoj ekonomických teorií. V takových cyklech popisuje vývoj hospodářskopolitických koncepcí např. Šulc 1993 nebo též Žák a Němcová 1997 a vývoj ekonomického myšlení mezi jinými např. Dow, Sheila C.: Macroeconomic Thought, A Methodological Approach, Oxford, Oxford University Press, 1985 apod./

Bez ohledu na takovéto z obecného pohledu naprosto nepodstatné modely lze říci, že jednou z odlišností sociologicko-ekonomických věd od věd fyzikálních je fakt evoluce funkcí jejich předmětu zkoumání směrem k rostoucí složitosti a specializaci, přičemž věda a poznání obecně jsou součástí tohoto vývoje.

Empirická báze předmětu ekonomie podléhá vývojovým změnám v takovém měřítku, které je ve fyzikálních vědách nepředstavitelné. Přijmeme-li pak tvrzení, že vývoj idejí hraje podstatnou roli ve vývoji společnosti a s tím i funkcí ekonomických vztahů, musíme připustit i opačné tvrzení, že evoluce ekonomického systému hraje roli ve vývoji ekonomického poznání a že tato role se při jisté dynamice evoluce ekonomiky stává jeho důležitou charakteristikou /Domnívám se, že tento fakt dokonce umožnil emancipaci ekonomie jako vědy s nejpropracovanějším teoretickým aparátem mezi společenskými vědami. Narozdíl např. od psychologie nemusela totiž těžit pouze z pozorování disfunkcí systému, ale mohla sledovat i emergenci některých důležitých funkcí systému v průběhu jeho evoluce./, která se projevuje i v praktikované metodologii ekonomů.

Na tuto metodologickou charakteristiku ekonomie upozornil sir John Hicks: "Nyní pouhý fakt, že ekonom se tak široce zabývá současnými záležitostmi, záležitostmi současnosti, mu dává určitou odpovědnost s ohledem na čas. Je to odpovědnost príbuzná odpovědnosti historika. Co je minulost pro historika, je současnost pro ekonoma. Práce každého z nich je v čase, v historickém čase, jako práce prírodovědce 
není. Experimentální věda je, ve své přirozenosti mimo čas, : pro podstatu experimentu musí být irelevantní, ke kterému datu je proveden nebo zopakován." /Hicks, Sir John: Causality in Economics, Oxford, Basil Blackwell, 1979a, str. 3/

Při odkazu na tuto charakteristiku ekonomie bych však doporučil spojení "ekonomie je v aktuálním čase", čímž je míněno, že ekonomická teorie poskytuje správné informace o fungování ekonomického systému pouze v pro ni ještě stále aktuálním kontextu reálné ekonomiky a mj. tedy i v aktuálním kontextu jejího aplikování a jejího chápání, neboli v kontextu "absorbce teorie" /Morgenstern 1972 viz. pozn. výše/ v chování jednotlivých ekonomických subjektů.

Mění-li se kontext, což zde znamená mimo jiné a to pouze mimo jiné, že se mění např. společenská struktura absorbce poznání, může ekonomická realita nejen vyžadovat nové teorie pro popis svého nového fungování, ale mưže také zneplatnit či zrelativizovat závěry teorií aktuálně daných. Teorie tak může čas, v němž je aktuální, předbíhat i za ním zaostávat. $V$ takovém prípadě je důležitější než kritika teorií spíše správná a aktuální interpretační implementace daných teorií na aktuální ekonomickou realitu, při níž je soutěž konkurenčních teorií víceméně vedlejším efektem, nebot' účelem zde není univerzální pravda co do obsahu a rozsahu, ale pouze co nejpravdivější aktuální interpretace.

\section{Evoluční metodologie a ekonomie}

Ačkoli se ekonomové stále posuzují podle ortodoxních kritérií tradiční metodologie jako ideálu pocházejícího z prírodních věd /viz. např. Hayek 1979/, v praxi uplatňují poněkud odlišný způsob myšlení /Např. Sheila C. Dow (viz. Macroeconomic Thought, A Methodological Approach, Oxford, Oxford University Press, 1985) jej nazývá babylónským oproti karteziánsko-euklidovskému./ Jsem přesvědčen, že oblíbenost postpozitivistické popperiánské metodologie mezi ekonomy /viz. Blaug, Mark: Economic Theory in Retrospect, 3. vyd., Cambridge University Press, 1978, str. 714/ Ize mimo jiné přičíst ideologické, či metafyzické príbuznosti paradigmatu ekonomie a Popperova evolučního paradigmatu /Darwinovská metoda učení pokusem a eliminací chyb oproti lamarckovské metodě zdůrazňující instrukci z okolí, resp. kritický racionalismus oproti naivnímu - Popper 1979 (1972), organicismu oproti mechanicismu - Bertallanffy 1967, evoluční racionalismus oproti konstruktivistickému či karteziánskému - Hayek 1979, teleologické myšlení oproti ontologicky-kauzálnímu - Engliš 1947 viz. Adamec 1994, divergence a selekce - Spinoza atp./ se základy ekonomie. Téměř axiomatické koncepty klasické ekonomie jako koncept konkurence a rovnováhy, koncepty efektivity, ale i dělby práce, směny a ceny, nákladů a výnosů atd. jsou všechny tohoto druhu.

Přirozeně pak ekonomy intelektuálně těší taková metodologie vědy, jež se hlásí k evolučnímu přístupu (An Evolutionary Approach /Podtitul jedné z Popperových zásadních knih Objective Knovledge, rev. vyd. Oxford, Oxford University Press, 1979 (1972)/) a vychází z evolucionismu jako z "metafyzického výzkumného programu" /Název kapitoly v Popperově intelektuální autobiografii Věčné hledání, Praha, Prostor, 
1995 (orig. 1990)/, metodologie vědy hovořící o konkurenčních teoriích vznikajících jako pokusné hypotézy v odpověd' na potřebu řešit problém a soutěžících o verisimilitude produkovanou úspěchem $v$ zásadních testech, jež jsou pokusy o jejich vyvrácení, a v neposlední řadě zdůrazňující svůj hypoteticko-deduktivní charakter oproti tradičnímu induktivnímu pohledu na metodu vědy, založenému na pozorování a experimentu.

Z pohledu této metodologie však hlavním problémem praxe ekonomické vědy zůstává omezenost testování ekonomických hypotéz vůči empirii a do značné míry i nemožnost jakéhokoli zásadnějšího testu, který by mohl směřovat k vyvrácení. /Zde se omezím pouze na toto konstatování, jehož důvody jsem vysvětlil jinde. viz. Adamec 1997 a 1998/. Ekonom konfrontovaný s tímto faktem nemůže uhájit metodologii vědy hovořící o nutné možnosti falsifikace (vyvrácení) teorie prostřednictvím zásadního testu jako o měřítku vědeckosti teorie a o úspěšném přežití dostatku zásadních testů jako o měřítku hodnocení verisimilitude (blížení pravdě) teorie. Čím více a čím zásadnějšími testy teorie projde, tím blíže je k pravdě. Nedostatek zásadních testů, jimž by mohla být teorie podrobena, znamená v Popperově logice nevyvratitelnost teorie a činí ji tak nevědeckou. /viz. Popper, 1979(72)/

\section{Výzkumné programy a ekonomie}

Ekonom teoretik respektující paradigma klasické ekonomie pak samozřejmě uvítá hájitelnou variantu evolučního popperiánství, která hovoří spíše o testování vědeckého výzkumného programu (historické řady teorií) než o testování teorie a o progresi či degeneraci programu spíše než o vyvrácení či přežití teorie samotné. Metodologie vědeckých výzkumných programů Imre Lakatoshe /viz. Lakatosh 1970 nebo Lakatosh, I.: The Methodology of Scientific Research Programmes, 1. díl jeho Philosophical Papers, vyd. John Worrall a Gregory Currie, Cambridge, Cambridge University Press, 1978/ odpovídá praxi ekonomie i tím, že součástí programu je tzv. ochranný pás, který není tvořen nezbytně svébytnými teoriemi, ale třeba jen zpưsoby ad-hoc vysvětlení neúspěchů teorií či technologií konstrukce "úspěšných" předpovědí. /viz. Adamec 1997,1998/

"Výzkumné programy" podpořily myšlenkovou příbuznost s ekonomií i rozšířením metodologie o další rys evolucionismu tím, že program degeneruje teprve a pouze, je-li vytlačován jiným, alternativním programem, jenž je pak označen za progresivní. Jakoby tak konkurenční programy soutěžily o jistou doménu či místo na trhu.

Oproti popperiánské "logické" škole kritického racionalismu však Lakatoshovy programy umožňuji i jisté subjektivistické, psychologicko-sociologické interpretace /viz. Adamec 1998/, příbuzné spíše Kuhnovým "vědeckým revolucím" /viz. Kuhn 1970/. Napríiklad k tomu, aby byl program označen za progresivnější, který údajně vytlačuje 
ostatní do degenerativní fáze, přispívá nejen to, že každý program "vidí" a umožňuje řešit "své" problémy (u Kuhna tzv. puzzle) a že problémy tohoto druhu právě v praxi vznikají nebo jsou z jiného důvodu aktuálně zajímavé, ale může $\mathrm{k}$ tomu postačit jen to, že vědci řeší právě ta a ta puzzle (někdy se překládá jako "hlavolamy") a ne jiná, nebot' když téměř nikdo nepracuje na podobných puzzle, jen těžko si jeho zajímavé puzzle najde obecenstvo, a naopak, pracují-li téměř všichni na aktuálních puzzle nějakého výzkumného programu, je práce na jeho ochranném pásu zajímavá jen proto.

Zatímco merkantilistická škola "viděla" národní bohatství, tak keynesiánství plnou zaměstnanost a monetarismus inflační projevy. Přechod většiny vědců, ekonomů od jednoho výzkumného programu ke druhému je ale někdy rychlý a hromadný a jindy pomalý, zpožděný a neúplný. Zatímco Keynesovy koncepty si v relativně krátkém čase podmanily jak vědeckou komunitu, tak hospodářskou politiku většiny demokratických vlád, Friedmanovy koncepty starší než jev hyperinflace si mnoho universitních ekonomů a učebnic teoretické ekonomie nepřisvojilo ani po letech jejich praktikování v hospodářské politice. Vždy je možno přebudovat ochranný pás. Na druhé straně kolem některých univerzit vznikly vědecké komunity omezující se výhradně na jeden výzkumný program. Co je pak ve vědecké praxi ekonomů kritériem pravdy? Na základě čeho může vědecká komunita ekonomů změnit názor?

\section{Hospodářská politika jako kompas vývoje}

Dovoluji si navrhnout hypotézu, že zásadní pro hodnocení konkurenčních ekonomických škol v ekonomii je (ne)úspěch té které vědeckou komunitou uznané "aplikace ekonomické teorie" v hospodářské politice.

Zjednodušeně by se dalo říci, že nejdůležitějším hybatelem vývoje ekonomických teorií je praxe hospodářské politiky a odvozeně popularita určitých hospodářskopolitických problémů a určité sociálně-ekonomické ideologie či doktríny mezi vládnoucími nebo $v$ jejich komunitě vedoucími vědci, politiky a experty. Takovéto sociologické vysvětlení je však třeba chápat pouze jako pomocné a nelze ho absolutizovat. Vedle tohoto vlivu existují další doplňující vysvětlení plynoucí z logiky kritické racionality vědeckého přístupu, byt' by se prosazovala pouze prostřednictvím "neracionálního" sociálního procesu. 
Neříkám, že hospodářskopolitická komunita rozhoduje o tom, která ekonomická škola jako součást doktríny nejlépe vyřeší konkrétní problémy, ba dokonce ani, že nějaká určitá škola je vůbec součástí hospodářskopolitické doktríny, ale jen to, že rozvoje dojde jen ta škola a teorie, jejíž obraz lze z nějakého důvodu nalézt ve výsledcích hospodářské politiky jako by $v$ ní byla správně aplikována nebo naopak naprosto očividně opominuta. Takto je třeba rozumět podmínce/předpokladu, že konkurenční ekonomická škola či teorie musí být nejprve "aplikována". /Jak formulace "jako by" odpovídá logice formulací předpokladů, a že tak Ize vyložit i jinak nereálné předpoklady vakua nebo ideální konkurence, viz. Friedman 1953 a Adamec 1996./

Teorie může být tedy pro ekonomickou vědu zajímavá anebo alespoň nadějná pouze, byla-li nebo může-li být opakovaně pozorována v takové své "aplikaci" a zároveň pozorována jako "úspěšně fungujíci" v komplexním ekonomickém systému, kterým je reálné hospodářství, tj. funguje-li v něm bez zásadních vedlejších nebo, chcete-li, nezamýšlených účinků a to alespoň po tzv. krátké období nebo $v$ tzv. dlouhém období, nebo častěji naopak fungují-li v něm právě takové vedlejší účinky, nezamýšlené hospodářskou politikou, které teorie předpovídá.

Teorie (či škola) v ekonomii dozrává z logického cvičení či slovní hry v uznávanou součást učebnic ekonomie pouze praktickou aplikací v praxi hospodářské politiky. Uznání její relevance a evidence jejích vysvětlení, její vypovídací schopnosti nastupuje masově až s užitím jejích argumentů pro provádění určité hospodářské politiky.

V genetice ekonomie je (oproti vývoji v prírodních vědách) selektivní vliv mutací v praxi (tj. $v$ hospodářské politice) na mutace $v$ teorii (či školách) řádově vyšší než $v$ opačném směru /O selekčním tlaku mutací vyšší, řídící genetické úrovně na mutace genů úrovní nižších, ilustrovaném na modelu letadla s automatickým pilotem viz. Popper 1979 (1972) a též Adamec 1994/. V tomto smyslu je praxe geneticky nadřazena teorii. Vývoj ekonomické teorie je vlečen praxí hospodářské politiky, jejími praktickými účely a aktuálními cíly.

\section{Proč právě a jen legitimita aplikace}

Mému tvrzení o prioritě úspěchu aplikace pro vývoj ekonomie přisuzuji především následující metodologické důvody:

1. Nedostatek empirické legality a popisné přesnosti /viz. Adamec 1997/ abstraktních teorií o komplexní ekonomické realitě znamená při značně problematických možnostech jejich empirického testování /viz. Adamec tamtéž/ absenci vnějšího kritéria pro racionální kritiku, což umožňuje trvalou diverzitu ekonomických škol a třeba i protimluvných teorií. 
2. Neodtržitelnost problémů hospodářské politiky od společenských a metafyzických problémů, problémů morálních, sociálních a kulturně historických, způsobuje rozdrobenost nejen v názorech ohledně účelů hospodářské politiky, ale i mezi ekonomickými školami tím, že omezuje racionální kritiku mezi nimi navzájem.

3. Z důvodu nepřetržitých strukturálních, příp. i funkčních změn ekonomické reality je ekonomie zakotvena v aktuálním čase. Nutnost průběžné kontextové re-aktualizace znamená pro soutěž ekonomických teorií a škol to, že hodnocení konkurentů následuje aktuální interpretační potřeby. Na druhou stranu však může tato vícerá re-aktualizace přispívat k odideologizování ekonomické teorie.

Z výše zmíněných dưvodů je vývoj ekonomie hlavně tažen za problémy hospodářské politiky, za vnějšími problémy, kterými je teorie neustále zásobována a které ji vědecky legitimují uvažováním o jejích "aplikacích". Aplikační legitimita jednotlivých ekonomických škol je dle mého názoru rozhodujícím kritériem jejich hodnocení a tak i vývoje ekonomie jako vědeckého oboru.

\section{Závěry pro vývoj ekonomie}

Definice kritéria, podle něhož jsou hodnoceny konkurenční ekonomické teorie úspěchem ve své aplikaci, vede k následujícím závěrům pro filosofii vědy, z nichž každý odpovídá jednomu z výše zmíněných východisek ve stejném pořadí:

1. Vývoj ekonomických teorií je veden více selekčním tlakem výsledků hospodářské politiky (a zprostředkovaně i strukturálních změn reálného hospodářství) než jejich testováním (mj. vůči empirii). Prioritním kritériem kritiky přitom není úspěch při přežití pokusů o vyvrácení teoretického řešení problému, který byl vyvolán zpravidla jiným, předchozím teoretickým řešením, resp. jeho vyvrácením (K. Popper), ale především (ne)úspěch jejich praktických předpovědí ("aplikací") při srovnání s reálnými výsledky hospodářské politiky (M. Friedman), které byly vyvolány zpravidla jinými předpověd'mi, resp. jejich úspěchem v nějaké vědecké, expertní či politické komunitě.

Prvotní je problém, tvrdí Popperova hypoteticko-deduktivní metodologie. Tímto prvotním problémem však v ekonomii není nejčastěji problém teorie samé. $V$ ekonomii se problém vědecký (např. potřeba přehodnocení nebo rozpracování určitých částí teorie, začlenění nových poznatků, vysvětlení vlastních selhání nebo zpochybnění nebezpečného konkurenta) nejčastěji odvozuje od problému hospodářskopolitického a jeho řešení.

2. Podstatná kritika a konkurence ekonomických teorií se odehrává převážně na tématech určovaných praxí hospodářské politiky a v konfrontaci s ní. Platí-li bod č. 1, pak tento závěr také znamená, že diverzita ekonomických škol, která má své ideologické kořeny, je jen těžko překonatelná kritikou uvnitř systému vědy /viz. též Myrdal, G.: The Political Element in the Development of Economic Theory, London, Routledge and Kegan Paul, 1953/, nebot' kritiku ohledně pozitivních závěrů ekonomické teorie Ize jen těžko oddělit od normativních aspektů hospodářské politiky. 
Prováděná hospodářská politika je vždy $v$ posledku definována normativně, a proto zůstane Friedmanův požadavek pozitivní ekonomie /1953/ jen normativním metodologickým doporučením bez větších šancí na své uskutečnění.

3. Hodnocení ekonomických teorií je dynamické v čase, což činí střídání progresivních a degenerativních fází jednotlivé školy vnitřně přirozeným a koexistenci konkurentů trvalou.

\section{Reflexe ekonomického výzkumu}

Tyto závěry je možno paralelně doplnit o některá subjektivní psychologickosociologická vysvětlení, která popisují stav a rizika vývoje ekonomického poznání:

1. Fakt, že vědecké problémy se v ekonomii odvozují od problémů hospodářskopolitických, si mnoho ekonomů vykládá tak, že nejlepší cestou k vědecké kariéře je koncentrace na horká témata hospodářské politiky.

Nemělo by se proto zapomínat, že úspěchy, o něž opravdu jde, slaví obecně platné teorie a jejich autoři, nikoli autoři konkrétních hospodářskopolitických analýz a doporučení.

2. Komunikace mezi teoretickými školami není pro ekonomy zajímavá ani tam, kde by kritika mohla vést ke korekci chyb, nebot' ochranné pásy teorií se vyvíjejí v prostředí trvalé koexistence, včetně ad-hoc teorií o přičinách vlastních neúspěchư při aplikaci a zpochybňování úspěchů konkurentů spočívajících ve vysvětlení nových jevů, která však do nich mohou být včleněna.

V pedagogické praxi to vede k dogmatizaci ekonomického poznání.

3. Neformuje se dominantní názor vědecké komunity - přechody vědců $k$ aktuálně progresivnější škole nejsou otázkou zachování vědecké cti, ale spíše naopak - což postupně ve svém výsledku vede k otupování myšlenkové vyhraněnosti u jejích jednotlivých členů a vytváření bezpečného, protože nekonfliktního, tzv. "středního proudu", díky němuž může skrytě dominovat i program v degenerativní fázi.

Příslušnost ke škole v degenerativní fázi není pro ekonoma nijak fatální a "neutralita", resp. př́islušnost ke všem školám najednou, je nejen možná, ale do určité míry i respektovaná / Na naší vysoké škole koluje vtip, že příslušnost ekonoma k jisté ideové škole ekonomie je jako krevní skupina každého ekonoma, ale že jsou i tací, kteří mají "nulku". (zeptat zda možno citovat a kdo je autorem)/.

Tyto procesy by byly dále umocňovány, byly-li by jejich principy adoptovány do praxe hospodářské politiky, což by mohlo konzervovat situaci, v níž by nebylo možno žádnou z ekonomických škol označit za opravdu progresivní, tj. za školu, která nejen 
vysvětluje úspěch svého konkurenta, ale poskytuje též možnosti budoucího výzkumu a potenciál k objevu opravdu nových jevů.

\section{Reflexe metody hospodářské politiky}

Hluboká krize ekonomického poznání však, zdá se, nehrozí, nebot' teoretici hospodářské politiky jsou stále schopni tvořivé interpretační aplikace různorodých, ale konzistentních teoretických východisek, byt' reflexe jejich vlastní metody nemusí být vždy specifikačně úplně přesná, což může dokumentovat následný citát.

"Opatření hospodářské politiky jsou odezvou na odchýlení ekonomické praxe od žádoucích záměrů lod stanovených hospodářských cílůl. Jde tudiž o cílovou orientaci, která vyžaduje spolehlivé informace o způsobu fungování národního hospodářství. Jedná se o subjektivní, ale prověřitelné informace o průběhu ekonomických procesů. Jsou formulovány tak, že mohou vysvětlit cílově orientované možnosti jednání. Těmto poznatkům říkáme technologické informace.

Získat tyto informace je úkolem ekonomické teorie. Jejich význam je o to větší, oč více jsou obecně platné. Teprve poznání ekonomických zákonitostí dovoluje, aby opatření hospodářské politiky byla nejen průhledná, ale aby i predpovědi a očekávání důsledků těchto opatření byly v daném období platné."

Jan Kasan: kap. 2. v Žák, Milan a kol.: Základy hospodářské politiky, str. 16-7

Čteme-li odzadu, pak čím obecně platnější ekonomická teorie, tím významnější technologické informace o způsobu fungování hospodářství poskytuje pro cílově orientovaná opatření hospodářské politiky. Tyto informace jsou však, jak čteme, sice prověřitelné, ale přeci jen subjektivní. Tzn., že ač ekonomická teorie dosahuje jisté úrovně obecné platnosti a umožňuje tak určité "poznání ekonomických zákonitostí", zůstává stále subjektivní. Nu, ani taková interpretace nemusí být daleko od pravdy, nebot' odpovídá praxi "teorie hospodářské politiky". /viz. Urban (1994, str. 9-10) rozlišuje užívání pojmu "hospodářská politika" jako označení praktické činnosti (prováděné např. vládou) a jako označení vědní disciplíny, neboli teorie hospodářské politiky, která analyzuje problémové situace, předkládá terapii, jejíž závěry a prípadná doporučení mohou být velice protichůdná, která nedochází vždy $\mathrm{k}$ jednoznačným závěrům, nabízí však alternativy, z nichž Ize vybírat. Takové užívání pojmu "teorie" dokresluje, jak hospodářská politika chápe a užívá opravdové ekonomické teorie. (kurzíva Urban, podtržení Adamec)/

V hospodářské politice jde totiž často spíše o to znát a vybrat teorii (a aplikaci), kterou Ize aplikovat na daný problém, než o to jak aplikovat danou ekonomickou teorii či školu na jí známé a/nebo aktuální problémy. Na rozdíl od teoretické ekonomie rozdělené těžko překonávanými rozdíly mezi školami panuje $v$ hospodářské politice často alespoň relativní nebo obecná shoda nejen o problému, jež má být řešen, ale i o možných nástrojích pro jeho řešení a jejich efektech. Vědec $v$ oboru hospodářská politika tak dle 
řešeného problému vybírá tomuto problému a jeho definici adekvátní teorii jako nástroj a jeho ideologická příslušnost či náklonnost $k$ nějaké ekonomické škole mưže být př́tomna v procesu výběru, přistupuje však více až ve fázi tvorby konkrétních doporučení.

At' už jsou ekonomické teorie aplikovány v hospodářské politice takto selektivně nebo dogmaticky jejich aplikace je víceméně interpretační v tom smyslu, že různé teorie jsou schopny interpretovat určité problémy hospodářské politiky a jiné ne. Jednou z nepominutelných technologických znalostí hospodářskopolitického vědce tak musí být aplikační prostor nebo okruh platnosti (viz. Adamec 1996) jednotlivých ekonomických teorií a škol.

\section{Literatura:}

Adamec, Radek: "Metodologie vědy a ekonomie", Praha, Sborník prací účastníků vědeckého semináře doktorského studia FIS VŠE v Praze, 1998

Adamec, Radek: "Ekonometrie a ekonomická teorie: přesnost kontra evidence", Praha, Sborník prací účastníků vědeckého semináře doktorského studia FIS VŠE v Praze, 1997, str. 3-7

Adamec, Radek: "Platí ekonomické teorie s nereálnými předpoklady?", Politická ekonomie 2-96, (1996), str.213-221

Adamec, Radek: Evoluční přístup ke společenským systémům a metodologie jejich poznávání, diplomová práce, VŠE v Praze, 1994

Bertalanffy, Ludwig von: Robots, Men and Minds, Psychology in the Modern World, New York, Braziller, 1967 (v češtině: Člověk, robot a myšlení, Praha, Svoboda, 1972)

Blaug, Mark: The Methodology of Economics or How Economists Explain, Cambridge, Cambridge University Press, 1980

Caldwell, Bruce: Beyond Psitivism, Londýn, Allen and Unwin, 1982

Engliš, Karel: Malá logika, Praha, Melantrich, 1947

Friedman, Milton: "The Methodology of Positive Economics" v Essays in Positive Economics, Chicago, Chicago University Press, 1953 (do češtiny přeložil Adamec, Radek: Metodologie pozitivní ekonomie, Praha, Centrum liberálních studií, 1997)

Hayek, Friedrich A. von: The Counter-Revolution of Science, Studies in the Abuse of Reason, 2. vyd., Indianopolis, Liberty Press, 1979 (též v češtině: Kontrarevoluce vědy)

Kasan, Jan a Žák, Milan a kol.: Hospodářská politika "A", Praha, VŠE v Praze, 1994 
Kuhn, Thomas: The Structure of Scientific Revolutions, Chicago, University of Chicago Press, 1970 (též slovensky: Štruktúra vedeckých revolúcií)

Lakatosh, Imre: "Falsification and the Methodology of Scientific Research Programmes" v Lakatos a Musgrave, vyd.: Criticism and the Growth of Knowledge, Londýn, Cambridge University Press, 1970, str. 91-196

Pheby, John: Methodology and Economics: A Critical Introduction, Londýn, Macmillan, 1988

Popper, Sir Karl R.: Věčné hledání, Intelektuální autobiografie, Praha, Prostor 1995 (orig. Uneded Quest, 1990)

Popper, Sir Karl R.: Objectice Knowledge, An Evolutionary Approach, Oxford, Oxford University Press, 1979 (1972)

Popper, Sir Karl R.: Conjectures and Refutations, 4. vyd., Londýn, Routledge and Kegan Paul, 1972(1963)

Redman, Deborah A.: Economics and the Philosophy of Science, Oxford, Oxford University Press, 1993

Šulc, Zdislav: Hospodářská politika, Praha, Consus, 1993

Urban, Zdeněk a kol.: Hospodářská politika, Praha, Victoria Publishing 1994

Žák, Milan a Němcová, Ingeborg: Učebnice hospodářské politiky I., Praha, VŠE v Praze, 1997

Žák, Milan a kol.: Základy hospodářské politiky, Praha, VŠE v Praze, 1995 